\title{
Growth and Yield of Okra (Abelmoschus esculentus Moench) as Influenced by Compost Application under Different Light Intensities
}

\author{
Victor A. DADA, Sifau A. ADEJUMO* \\ University ofIbadan, Department of Crop Protection and Environmental Biology, Ibadan, Nigeria; nikade 05@yahoo.com (*corresponding author)
}

\begin{abstract}
Okra (Abelmoschus esculentus) is one of the popular vegetables, especially rich in iron, vitamins and other minerals. Poor soil fertility and inconsistent light intensity, due to unfavorable weather condition, reduce okra performance. Response of two okra varieties ('NH47-4' and 'Clemson spine') to different rates of compost (0, 5, 10 and $15 \mathrm{t} / \mathrm{ha}$ ), under different light intensities (L0: control (no reduction) or 100\% light intensity, L1: 33\%, L2: 46\% and L3: 76\%, light reduction) were assessed in pot and field trials. The experimental design was a factorial experiment fitted in a randomized complete block design (RCBD). Data on growth and yield attributes were collected. The results showed that the reduction in light intensity (L3) increased the numbers of fruits and leaf area by 50 and $47 \%$ respectively on the field, but delayed flowering. High light intensity (L0) though enhanced leaf area formation and early flowering, but hastened leaf senescence and abscission. Compost generally increased growth rate, leaf area and dry matter accumulation of the two okra cultivars compared to control under varying light intensities. Compost at $15 \mathrm{t} /$ ha performed better and increased fruit number by $66 \%$ on the field. Between the two cultivars, 'Clemson spine' responded better than 'NH47-4' plants in terms of yield. Low light intensity ( $76 \%$ light reduction) in combination with higher compost rate however enhanced prolonged fruiting and leaf formation in the two okra varieties. The application of compost at 15 $\mathrm{t} / \mathrm{ha}$ is therefore recommended for optimum yield of okra under low light intensity.
\end{abstract}

Keywords: light, nutrients, okra, organic amendment, soil, yield

\section{Introduction}

Okra (Abelmoschus esculentus (L.) Moench) belongs to the Malvaceae family and is one of the most popular fruit vegetables cultivated in Africa (Schippers, 2000) and other places around the world (NIHORT, 1986). It is cultivated for its fibrous fruits or pods and the fruits are harvested when immature and eaten as a vegetable. They are a good source of carbohydrate, protein, fats, vitamins and minerals (Akintoye et al., 2011). Apart from its popular use as vegetable, it has also been used for several purposes such as coffee additive and paper making (Moekchantuk and Kumar, 2004). The mucilage is also suitable for medicinal and industrial applications (Akinyele and Temikotan, 2007). However, despite the nutritional values of okra and its geographical distribution, as well as adaptability to varying climatic conditions, the yield of okra is still very low. This was attributed to continuous decline in soil fertility, especially in the tropics, and unstable climatic conditions. Normally, okra, being a tropical plant, grows well under warm conditions with sufficient moisture levels and light intensities. With the recent change in climate and the problem of soil fertility, the yield of okra has been reduced. Okra production is being constrained by a complex of biotic and abiotic factors at every stage of growth (Anne and Carter, 2004).

Unfavorable climatic conditions such as drought, edaphic factors, excess or low light intensity can damage the quality and reduce the yield (Agbogidi and Nweke, 2005). Light is an absolute requirement for plant growth and development, next to water. This is because an increase in the light intensity will result to an increase in the rate of photosynthesis. Light modifies the anatomy and physiology of leaf (Wilson and Coope, 1969). It is reported that plants grown under high light intensity are capable of stronger photosynthesis than those grown under weaker light (Knorr and Vegtmann, 1983). Leafs formed in shade are also thinner than those formed under sun or high light intensity. Meanwhile, different plants have optimum light requirements for optimum performance and both low and high/excessive light intensities are injurious to plant growth. When in excess, light inhibits stem growth due to its effect on gibberellins while deficit in light intensities tends to reduce plant growth, development and yield (Vergara, 1978). This is because low amount of solar energy is said to reduce the rate of photosynthesis and below a certain/minimum light intensity, the plant growth will fall below what is called the 'compensation point' (Edmond et al., 1978). Optimum light requirement by a particular crop must therefore be determined.

However, with the optimum light intensity, crop performance can also be limited by inadequate availability of essential nutrients in the soil (Akande et al., 2010). Fertilizer is an important input contributing to crop production because it increases productivity and improves yield quality and quantity (Adeniyan and Ojeniyi, 2003). On the contrary, inorganic fertilizers release nutrients quickly, but most of 
218

them leach out easily. Besides, the environmental and health implications coupled with the high price of mineral fertilizers and irregularities in its supply have made the use of synthetic fertilizers unrealistic for farmers, particularly vegetable crop growers (Olasantan, 1991). Meanwhile, longer residual effects of organic manures when applied to the soil have been reported (Adeniyan and Ojeniyi, 2003). Addition of organic amendments to soil at different rates has been reported to increase the yield of okra (Akanbi, 2002) and improved the soil nutrient contents (Akanbi et al., 2000; El-Magd et al., 2006; Garg and Bahla, 2008; Haynes and Naidu, 1998).

Several works have also been carried out on the study of light intensity on the photoregulation of plant (Sanwal et al., 2007), but very little work has been done on the specific effect of light intensity on the growth and physiology of okra most especially in combination with different organic amendments. It has therefore become necessary to develop alternative ways to boost okra production under different light intensities. The major aim of this study therefore was to investigate the effect of different light intensities and compost application, as well as their interaction on the growth and yield of okra under greenhouse and field conditions. The optimum light and fertilizer requirements were also determined.

\section{Materials and methods}

The study was conducted at the Department of Crop Protection and Environmental Biology, Faculty of Agriculture and Forestry, University of Ibadan, Ibadan, Nigeria. The study area falls within latitude $7.34 \mathrm{~N}$ and longitude $3.54 \mathrm{E}$ at an altitude of $200 \mathrm{~m}$, with annual rainfall between $1,250 \mathrm{~m}$ to $1,500 \mathrm{~m}$ spanning eight $(8)$ months (March-October) with dry spell in August, annual average temperature is $21.30^{\circ} \mathrm{C}$ and relative humidity of $70-80 \%$.

Two major cultivated okra species in Nigeria, which are already differentiated by their reaction to day light, variety 1 (V1 = 'Clemson spine'; Abelmoschus esculentus) which is a day neutral and variety 2 (V2 = 'NH47-4'; Abelmoschus callei) which is a short day (NIHORT, 1986) were used for this study (Fig. 1).

\section{Soilsampling and preparation}

In order to characterize the soil used for the experiment, samples were taken across the field to a depth of $0-15 \mathrm{~cm}$ with the use of soil auger and a bulked sample was taken for laboratory analysis. In the laboratory, soil samples were airdried, crushed using mortar and pestle and then sieved through the $0.5 \mathrm{~mm}$ and $2 \mathrm{~mm}$ mesh. The sieved samples were analyzed for soil physico-chemical characteristics at the Analytical Laboratory of the International Institute of Tropical Agriculture, Ibadan, Nigeria, using standard procedures (IITA, 1979). The result of soil physico-chemical analysis is as shown in Table 1.

\section{Composting procedure}

Compost was prepared from Mexican sunflower (Tithonia diversifolia) and poultry manure. These were mixed in the ratio 3:1 using Partially Aerated Composting Technology (Adediran et al., 2001). The compost was monitored till maturity, turning and watering were done fortnightly. After three months, the matured compost was evacuated from the bucket, air dried and later sieved to remove the shaft, shredded and bagged.

\section{Experimental procedures}

The experiment comprised of pot and field experiments. For pot experiment, a total of ninety-six pots were used; they were filled with top soil collected from the site, which was later used for the field experiment; the experimental design was a $4 \times 4 \times 2$ factorial experiment fitted into randomized complete block design, with three replicates. The quantities of compost applied per pot to give the equivalent rates of compost/ha were Compost $0(\mathrm{C} 0=$ control $)$, Compost 1 $(\mathrm{C} 1=5 \mathrm{t} / \mathrm{ha}=12.5 \mathrm{~g}$ for $5 \mathrm{~kg}$ soil $)$, Compost $2(\mathrm{C} 2=10$ $\mathrm{t} / \mathrm{ha}=25 \mathrm{~g}$ for $5 \mathrm{~kg}$ soil) and Compost $3(\mathrm{C} 3=15 \mathrm{t} / \mathrm{ha}=$ $37.5 \mathrm{~g}$ for $5 \mathrm{~kg}$ soil). Each compost rate was thoroughly mixed with $5 \mathrm{~kg}$ soil. The pots were watered to field capacity and a sauce pan placed under each pot to collect the leachates; planting was done after a week. The light intensity was reduced with the use of net wire mesh of $0.5 \mathrm{~mm}$, one layer is $33 \%$ reduction (L1), two layers (46\%) reduction (L2) and three layers $(76 \%)$ reduction (L3) respectively, while no light reduction (L0) served as control. Light meter was used to determine the intensity of the light.

\section{Field experiment}

\section{Planting and experimental design}

From the results of the pot experiment and based on different growth parameters considered, the okra variety that performed better (variety Clemson spine) was considered

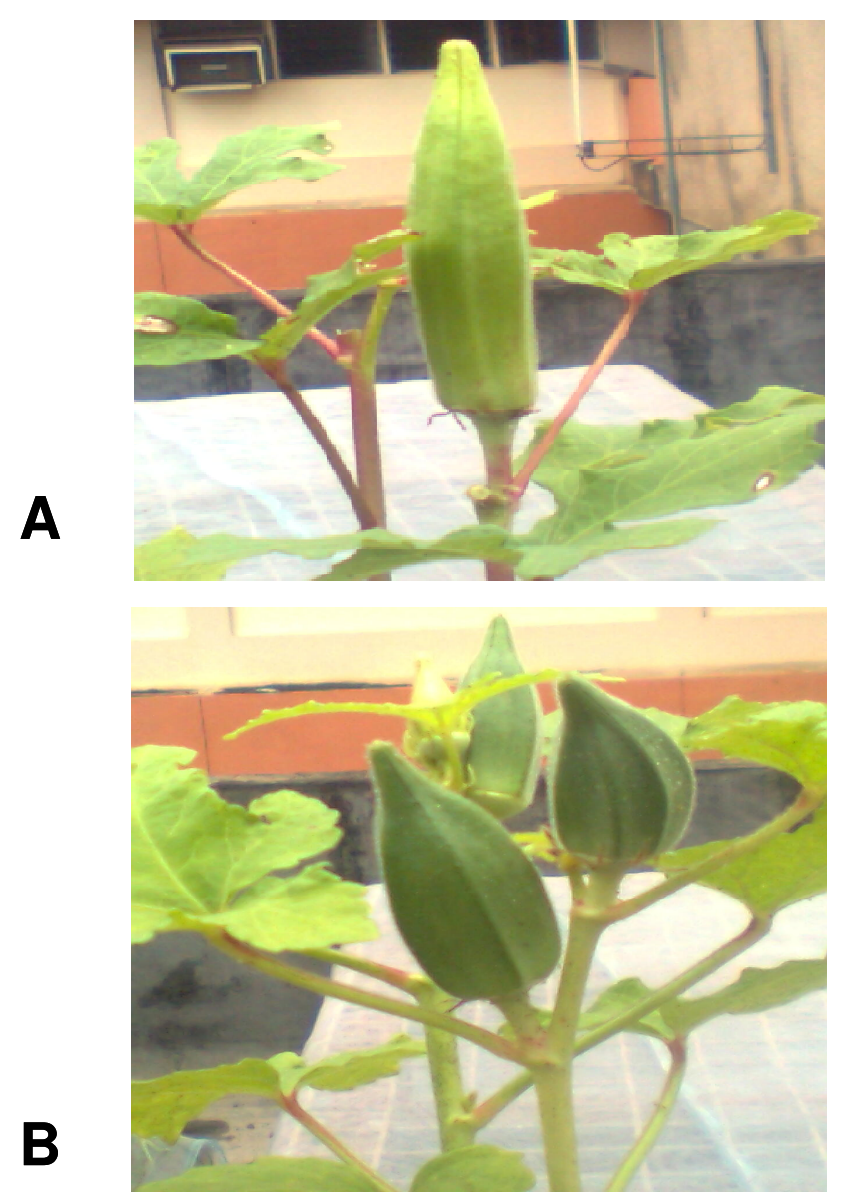

Fig. 1. Two types of okra species used (A) 'Clemson spine' and (B) 'NH47-4' 
Table 1. Physico-chemical properties of experimental soil

\begin{tabular}{|c|c|c|c|c|c|c|c|c|c|c|c|}
\hline Soil properties & $\mathrm{pH}\left(\mathrm{H}_{2} \mathrm{O}\right)$ & $\mathrm{OC}(\%)$ & $N(\%)$ & $\begin{array}{c}\mathrm{P} \\
(\mathrm{mg} / \mathrm{kg})\end{array}$ & $\mathrm{Ca}$ & $\mathrm{Mg}(\mathrm{cmol} / \mathrm{kg})$ & $\mathrm{K}$ & $\mathrm{Na}$ & ECEC & $\mathrm{Fe}(\mathrm{mg} / \mathrm{kg})$ & $\mathrm{Zn}(\mathrm{mg} / \mathrm{kg})$ \\
\hline BCA & 6.7 & 1.91 & 0.14 & 245.69 & 303.84 & 0.89 & 0.18 & 0.09 & 13.53 & 164.5 & 44.79 \\
\hline
\end{tabular}

further for field experiment. Similarly with respect to light intensity one layer (L1) or 33\% light reduction and three layers (L3) or $76 \%$ light reduction performed better than the $46 \%$ light reduction and they were therefore, tried on the field. The land for the field experiment was prepared manually. There were four blocks, with each block consisting of nine beds/plots, making a total number of thirty-six beds, with each bed measuring $1 \times 1 \mathrm{~m}$ and $0.5 \mathrm{~m}$ in between beds, and block size of $13 \times 5.5 \mathrm{~m}$. The total land area used was 71.5 $\mathrm{m}^{2}$. The seeds of okra ('Clemson spine') were planted with two seeds per hole at a spacing of $0.4 \times 0.30 \mathrm{~m}$. Thinning was done after the establishments of plants to give two plants per stand. The experimental design was $3 \times 3$ factorial experiment fitted in a randomized complete block design. The treatments applied were C0 (control), C1 (5 t/ha) and C3 (15 t/ha). The insecticide cypermethrin was sprayed on the okra plants at 4-5 weeks after planting (WAP), in order to eliminate okra pests (leaf roller Syleptic derogata, white flies, Bemisia sp.). Compost amendment procedure was done as in the pot experiment.

\section{Data collection}

Two weeks after planting, data on growth and yield parameter were collected. These were: numbers of fruit, time to flower, numbers of leaves, leaf area and stem height (which was measured from the ground level to the base of the youngest unfolded leaf with a ruler). At plant maturity, the plants were uprooted and taken to the laboratory. The uprooted plants were partitioned into leaf stem and root. The fresh weight and dry weight of the plants were obtained and they were separately packed into envelopes and oven dried at $80{ }^{\circ} \mathrm{C}$ until constant weights were obtained, the fresh fruit after weighing were also dried for determination of dry matter accumulation.

\section{Statistical analysis}

Statistical analysis were done using Gen stat software where $F$ value were significant, means were separated by least significant difference (LSD) at $\mathrm{P}<0.05$.

\section{Results}

The effect of compost application and light intensity on the vegetative growth of two cultivars of okra in the pot experiments

Seventy-six percent reductions in light intensity (L3) gave the highest number of leaves and plant height, while the lowest mean was recorded in L2. With 33\% reduction in light intensity, the two cultivars produced more fruit per plant. Days to flower was also reduced with low light intensity (L3 $=76 \%$ reduction) and was prolonged under high light intensity (LO $=0 \%$ reduction). The trend was such that the higher the light intensity, the more the number of days required for flowering and vice-versa. This was also reflected in the number of fruits with lower light intensity, plants producing more fruits than the ones exposed to higher light intensity. Statistically, there was no difference in the number of leaves and leaf area under varying light intensities (Table 2). Increase in the level of compost application was found to increase the days to flower more than control. With respect to number of leaf, compost 3 (the highest compost rate) had the highest mean, followed by Compost 2 and were better

Table 2. Effect of different light intensities on the vegetative growth of the okra in the potexperiment

\begin{tabular}{lccccc}
\hline $\begin{array}{l}\text { Light } \\
\text { intensity } \\
(\mathrm{klx})\end{array}$ & $\begin{array}{c}\text { Plant } \\
\text { height } \\
(\mathrm{cm})\end{array}$ & $\begin{array}{c}\text { Number } \\
\text { of leaves } \\
(\mathrm{no})\end{array}$ & $\begin{array}{c}\text { Days to } \\
\text { flower } \\
(\mathrm{no})\end{array}$ & $\begin{array}{c}\text { Leaf } \\
\text { area } \\
\left(\mathrm{cm}^{2}\right)\end{array}$ & $\begin{array}{c}\text { Numbers } \\
\text { of fruit } \\
(\mathrm{no})\end{array}$ \\
\hline L0 & 23.89 & 8.02 & 33.23 & 32.51 & 0.90 \\
L1 & 23.67 & 8.09 & 30.93 & 36.35 & 1.43 \\
L2 & 22.19 & 8.02 & 28.44 & 33.88 & 1.07 \\
L3 & 25.57 & 8.42 & 18.44 & 34.72 & 1.37 \\
Prob of F & $\mathrm{X}$ & $\mathrm{NS}$ & $\mathrm{X}$ & $\mathrm{NS}$ & $\mathrm{X}$ \\
LSD & 1.6 & 0.62 & 3.03 & 3.12 & 0.21 \\
\hline
\end{tabular}

The values are the mean of the two maize varieties under different light intensities; Ns: Not Significant at $\mathrm{P}<0.05$; X: Significant difference at $\mathrm{P}<0.05$; L0- Control; $\mathrm{L} 1=33 \%$ light reduction; $\mathrm{L} 2=46 \%$ light reduction; $\mathrm{L} 3=76 \%$ light reduction; LSD $=$ Least Significant Difference

Table 3. Effect of different compost application rates on the vegetative growth of okra in the pot experiment

\begin{tabular}{lccccc}
\hline $\begin{array}{l}\text { Compost } \\
\text { level (t/ha) }\end{array}$ & $\begin{array}{c}\text { Plant } \\
\text { height } \\
(\mathrm{cm})\end{array}$ & $\begin{array}{c}\text { Number } \\
\text { of leaves }\end{array}$ & $\begin{array}{c}\text { Days to } \\
\text { flower }\end{array}$ & $\begin{array}{c}\text { Leaf } \\
\text { area } \\
\left(\mathrm{cm}^{2}\right)\end{array}$ & $\begin{array}{c}\text { Numbers } \\
\text { of fruit } \\
(\mathrm{no})\end{array}$ \\
\hline C0 & 22.21 & 7.19 & 24.26 & 34.46 & 1.26 \\
C1 & 21.85 & 8.03 & 22.85 & 35.51 & 1.12 \\
C2 & 24.36 & 8.43 & 26.95 & 32.05 & 1.20 \\
C3 & 23.90 & 8.90 & 26.98 & 36.44 & 1.16 \\
Prob of F & $\mathrm{NS}$ & $\mathrm{X}$ & $\mathrm{NS}$ & $\mathrm{NS}$ & $\mathrm{NS}$ \\
LSD & 1.694 & 0.624 & 3.05 & 4.93 & 0.21 \\
\hline
\end{tabular}

The values are the mean of the two maize varieties under different compost rates; Ns: Not Significant at $\mathrm{P}<0.05$; X: Significant difference at $\mathrm{P}<0.05$; C0- Control; $\mathrm{Cl}=5 \mathrm{t} / \mathrm{ha} ; \mathrm{C} 2=10 \mathrm{t} / \mathrm{ha} ; \mathrm{C} 3=15 \mathrm{t} / \mathrm{ha} ; \mathrm{LSD}=$ Least Significant Differences

than the control (Table 3). It was observed that, Compost 3 also supported the production of leaf area in the okra plants though there was no significant $(\mathrm{P}<0.05)$ difference in the leaf area. Except for number of leaf, there was no significant difference in the plant height, days to flower and numbers of fruits, in response to compost application.

\section{Interactive effects of compost application and light intensity} on the vegetative growth of two varieties of okra

On the interactive effect of different light intensity and compost application, there were differences among the cultivars. Variety two generally performed better than variety one in all the growth parameters taken. Under high light intensity (L0), addition of highest rate of compost (C3) enhanced the growth of plant with respect to height for the two varieties. For number of leaf, the trend was the same for variety 1 , but $\mathrm{C} 2$ performed better than other compost rates for variety 2. Compared to control, days to flower under high light intensity were reduced with the application of C3 and $\mathrm{C} 1$ for variety 2 and application of $\mathrm{C} 1$ and $\mathrm{C} 2$ for variety 1 . For the leaf area production under L0, application of $\mathrm{C} 2$ 
Table 4. Interactive effects of compost application and light intensity on the vegetative growth of two varieties of okra in the pot experiment

\begin{tabular}{|c|c|c|c|c|c|c|c|}
\hline $\begin{array}{l}\text { Light intensity } \\
\text { (Klux) }\end{array}$ & Cultivar & $\begin{array}{c}\text { Compost } \\
\text { t/ha }\end{array}$ & Plants height $(\mathrm{cm})$ & $\begin{array}{c}\text { No of leaves } \\
\text { (no) }\end{array}$ & $\begin{array}{l}\text { Days to flower } \\
\text { (no) }\end{array}$ & $\begin{array}{c}\text { Leaf area } \\
\left(\mathrm{cm}^{2}\right)\end{array}$ & $\begin{array}{c}\text { Number of fruit } \\
\text { (no) }\end{array}$ \\
\hline \multirow[t]{8}{*}{ L0 } & V1 & $\mathrm{C} 0$ & 9.13 & 5.87 & 11.13 & 39.95 & 0.17 \\
\hline & & $\mathrm{C} 1$ & 5.73 & 7.60 & 6.73 & 36.23 & 0.40 \\
\hline & & $\mathrm{C} 2$ & 10.47 & 7.93 & 9.47 & 46.66 & 0.80 \\
\hline & & $\mathrm{C} 3$ & 32.87 & 8.87 & 22.87 & 40.98 & 1.33 \\
\hline & V2 & $\mathrm{C} 0$ & 24.00 & 8.20 & 14.00 & 27.60 & 0.87 \\
\hline & & $\mathrm{C} 1$ & 11.67 & 8.47 & 9.67 & 29.28 & 1.13 \\
\hline & & $\mathrm{C} 2$ & 26.33 & 8.80 & 22.33 & 33.82 & 1.40 \\
\hline & & $\mathrm{C} 3$ & 37.60 & 8.40 & 9.60 & 24.53 & 1.80 \\
\hline \multirow[t]{8}{*}{ L1 } & V1 & $\mathrm{C} 0$ & 13.40 & 8.07 & 25.67 & 42.29 & 1.47 \\
\hline & & $\mathrm{C} 1$ & 25.67 & 7.07 & 25.67 & 32.05 & 0.93 \\
\hline & & $\mathrm{C} 2$ & 29.87 & 7.00 & 29.87 & 29.82 & 1.33 \\
\hline & & $\mathrm{C} 3$ & 29.07 & 9.33 & 29.07 & 38.36 & 1.33 \\
\hline & V2 & $\mathrm{C} 0$ & 23.53 & 9.80 & 33.53 & 38.12 & 1.93 \\
\hline & & $\mathrm{C} 1$ & 32.53 & 9.00 & 32.53 & 32.47 & 1.33 \\
\hline & & $\mathrm{C} 2$ & 30.40 & 9.13 & 30.40 & 28.21 & 1.400 \\
\hline & & $\mathrm{C} 3$ & 33.00 & 7.73 & 33.40 & 49.47 & 1.667 \\
\hline \multirow[t]{8}{*}{ L2 } & V1 & $\mathrm{C} 0$ & 22.33 & 6.33 & 22.30 & 26.63 & 1.267 \\
\hline & & $\mathrm{C} 1$ & 23.47 & 7.73 & 23.47 & 22.11 & 0.933 \\
\hline & & $\mathrm{C} 2$ & 31.07 & 9.07 & 31.07 & 20.41 & 1.000 \\
\hline & & $\mathrm{C} 3$ & 33.53 & 9.27 & 33.53 & 23.09 & 1.000 \\
\hline & V2 & $\mathrm{C} 0$ & 22.07 & 5.17 & 22.07 & 31.49 & 1.000 \\
\hline & & $\mathrm{C} 1$ & 30.67 & 9.47 & 30.67 & 39.29 & 1.267 \\
\hline & & $\mathrm{C} 2$ & 30.87 & 7.40 & 30.87 & 24.56 & 1.333 \\
\hline & & $\mathrm{C} 3$ & 33.53 & 9.73 & 33.53 & 32.49 & 0.800 \\
\hline \multirow[t]{8}{*}{ L3 } & V1 & $\mathrm{C} 0$ & 23.53 & 6.47 & 43.53 & 33.62 & 1.000 \\
\hline & & $\mathrm{Cl}$ & 33.47 & 5.73 & 23.47 & 34.03 & 1.200 \\
\hline & & $\mathrm{C} 2$ & 30.40 & 10.47 & 30.40 & 28.98 & 1.333 \\
\hline & & $\mathrm{C} 3$ & 36.73 & 7.40 & 27.73 & 30.71 & 1.133 \\
\hline & V2 & $\mathrm{C} 0$ & 24.07 & 7.60 & 34.07 & 38.97 & 1.667 \\
\hline & & $\mathrm{C} 1$ & 30.60 & 9.13 & 30.60 & 32.65 & 1.733 \\
\hline & & $\mathrm{C} 2$ & 31.20 & 7.67 & 31.20 & 30.94 & 1.467 \\
\hline & & C3 & 37.53 & 10.27 & 36.53 & 31.87 & 1.200 \\
\hline Prob of $F$ & & & $\mathrm{X}$ & NS & $\mathrm{X}$ & NS & $\mathrm{X}$ \\
\hline LSD & & & 0.50 & 1.770 & 6.00 & 12.48 & 0.4 \\
\hline
\end{tabular}

Ns: Not Significant at P < 0.05; X: Significant difference at P < 0.05; L0- Control; L1 = 33\% light reduction; L2 = 46\% light reduction; L3 = 76\% light reduction; C0Control; $\mathrm{C} 1=5 \mathrm{t} / \mathrm{ha} ; \mathrm{C} 2=10 \mathrm{t} / \mathrm{ha} ; \mathrm{C} 3=15 \mathrm{t} / \mathrm{ha} ; \mathrm{LSD}=$ Least Significant Difference

performed better than other compost rates. However, the positive effects of compost application were shown clearly in the number of fruits and there was an increase in fruit number of the two varieties as compost rate increases. In control, with reduction of light intensity at L1 (33\%), an increase in plant height was observed for the two varieties. Compost application generally increased the plant height compared to control and the higher the compost rate, the taller the plant. Effect of different compost rates and L1 intensity was not significant on leaf area, number of leaf and fruits for V1 and the trend was the same for V2, except for the leaf area, which increased with increase in compost application compared to control. Under L2 (46\%) however, compost application enhanced the performance of the two okra varieties, in terms of plant height and number of leaf, as well as number of fruit for V2. It was observed that days to flower increased in the two varieties with compost application. L3 ( $76 \%$ reduction) in combination with different compost rates also performed better than control on the plant height and number of leaf and fruits. Generally, the interactive effect of compost and light intensity on plant height and number of fruit was significant compared to control. Light intensity 3 (L3) performed better than other treatments in terms of numbers of fruits (Table 4).
The effect of light intensity and compost application on the dry matter accumulation of okra in the pot experiment

Effect of compost application and light intensity on the yield parameters of okra plants showed that the fresh fruit weight increased with increase in compost rates, while there was a reverse in the case of dry weight, with control having the highest dry weight. The leaf fresh weight, root fresh and dry weight increased with application of C2 compared with control (Fig. 2). The effect of light was pronounced on both cultivars and all the parameters assessed were significantly $(\mathrm{P}$ $<0.05$ ) different. The lowest light intensity (L3) increased the fruit fresh weight followed by the highest light intensity (L0) which also had the highest dry weight (Fig. 3). The interactive effect of the treatments showed that there were no significant $(\mathrm{P}<0.05)$ differences among the parameters assessed. Meanwhile, with respect to the fresh fruit and leaf weights an increase was recorded with respect to compost rates 2 and 3 under the highest light intensity compared with the control in variety 1 . Addition of compost at $15 \mathrm{t} / \mathrm{ha}$ boost the production of okra leaf and the highest mean value for fresh leaf weight was recorded for variety 2 using compost 3 . Furthermore, there is an increase in mean among all levels of compost, as levels of compost application increased the fresh weight in both cultivars. Under L1 (33\% light reduction), 
Table 5. Interactive effect of compost application on the fresh weight of two cultivars of okra in the pot experiments

\begin{tabular}{|c|c|c|c|c|c|c|}
\hline Intensity & Varieties & Compost & Fresh leaves & Fresh root & Fresh fruit & Fresh stem \\
\hline \multirow{8}{*}{ L0 } & V1 & C0 & 4.33 & 11.96 & 26.16 & 15.51 \\
\hline & & $\mathrm{C} 1$ & 6.00 & 14.00 & 10.87 & 7.61 \\
\hline & & $\mathrm{C} 2$ & 11.07 & 12.64 & 32.47 & 12.66 \\
\hline & & C3 & 10.00 & 5.42 & 36.70 & 12.05 \\
\hline & $\mathrm{V} 2$ & $\mathrm{C} 0$ & 3.43 & 4.09 & 30.76 & 17.12 \\
\hline & & $\mathrm{C} 1$ & 5.98 & 4.47 & 20.58 & 11.07 \\
\hline & & $\mathrm{C} 2$ & 7.27 & 5.49 & 20.58 & 21.47 \\
\hline & & C3 & 13.88 & 4.91 & 8.21 & 18.11 \\
\hline \multirow{8}{*}{ L1 } & $\mathrm{V} 1$ & $\mathrm{CO}$ & 3.45 & 5.66 & 8.64 & 9.68 \\
\hline & & $\mathrm{C} 1$ & 3.23 & 2.93 & 11.67 & 7.89 \\
\hline & & $\mathrm{C} 2$ & 1.48 & 5.44 & 6.56 & 11.90 \\
\hline & & C3 & 4.44 & 4.22 & 11.18 & 14.68 \\
\hline & $\mathrm{V} 2$ & $\mathrm{C} 0$ & 3.53 & 4.71 & 22.30 & 12.71 \\
\hline & & $\mathrm{C} 1$ & 1.89 & 4.46 & 8.11 & 11.38 \\
\hline & & $\mathrm{C} 2$ & 1.44 & 4.54 & 15.77 & 13.67 \\
\hline & & C3 & 2.72 & 4.28 & 24.73 & 11.70 \\
\hline \multirow{8}{*}{ L2 } & V1 & $\mathrm{CO}$ & 3.96 & 3.91 & 0.49 & 11.51 \\
\hline & & $\mathrm{C} 1$ & 5.76 & 5.49 & 5.93 & 17.11 \\
\hline & & $\mathrm{C} 2$ & 2.45 & 4.21 & 8.70 & 9.84 \\
\hline & & C3 & 12.87 & 2.82 & 6.54 & 8.19 \\
\hline & $\mathrm{V} 2$ & $\mathrm{C} 0$ & 3.94 & 2.70 & 11.66 & 10.74 \\
\hline & & $\mathrm{C} 1$ & 2.18 & 2.68 & 7.20 & 5.93 \\
\hline & & $\mathrm{C} 2$ & 1.23 & 3.03 & 7.38 & 6.57 \\
\hline & & C3 & 11.99 & 2.08 & 16.17 & 11.74 \\
\hline \multirow{8}{*}{ L3 } & V1 & C0 & 12.04 & 12.98 & 5.89 & 12.11 \\
\hline & & $\mathrm{C} 1$ & 4.74 & 2.52 & 19.85 & 14.96 \\
\hline & & $\mathrm{C} 2$ & 1.68 & 2.39 & 10.90 & 10.05 \\
\hline & & C3 & 14.65 & 13.28 & 9.91 & 16.46 \\
\hline & $\mathrm{V} 2$ & $\mathrm{C} 0$ & 5.49 & 5.34 & 15.75 & 10.85 \\
\hline & & $\mathrm{C} 1$ & 2.41 & 5.39 & 15.68 & 11.88 \\
\hline & & $\mathrm{C} 2$ & 11.00 & 7.55 & 15.60 & 11.13 \\
\hline & & C3 & 6.94 & 5.77 & 15.70 & 9.18 \\
\hline Probability of 'F' & & & NS & NS & NS & NS \\
\hline LSD & & & 467 & 5.27 & 10.04 & 8.28 \\
\hline
\end{tabular}

$\mathrm{C} 0$ - Control; C1 = 5 t/ha; C2 = 10 t/ha; C3 = 15 t/ha; L0- Control/No reduction; L1- 33\% light reduction; L2- 46\% light reduction; L3- 76\% light reduction; V1 = Variety $1 ; \mathrm{V} 2=$ Variety 2; LSD = Least Significant Difference

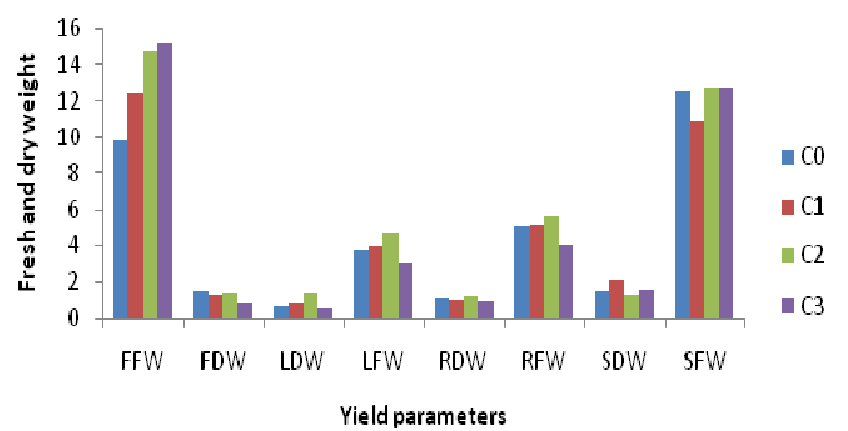

Fig. 2. Main effect of compost application on the yield parameters of two cultivars of okra in the pot experiment

The values are the mean of the two maize varieties under different compost rates; C0- Control; C1 = 5 t/ha; C2 = $10 \mathrm{t} / \mathrm{ha} ; \mathrm{C} 3=15 \mathrm{t} / \mathrm{ha}$; FFW = Fresh Fruit Weight; FDW = Fruit Dry Weight; LDW = Leaf Dry Weight; LFW = Leaf Fresh Weight; RDW = Root Dry Weight; RFW = Root Fresh Weight; SDW = Stem Dry Weight; SFW = Stem Fresh Weight

application of C3 also increased fresh fruit and stem weights of variety 1 compared to control, whereas the effect was not significant on variety 2 . With $46 \%$ light reduction, higher compost application was superior on fresh leaf weight, while fruit fresh weight responded positively to all the compost

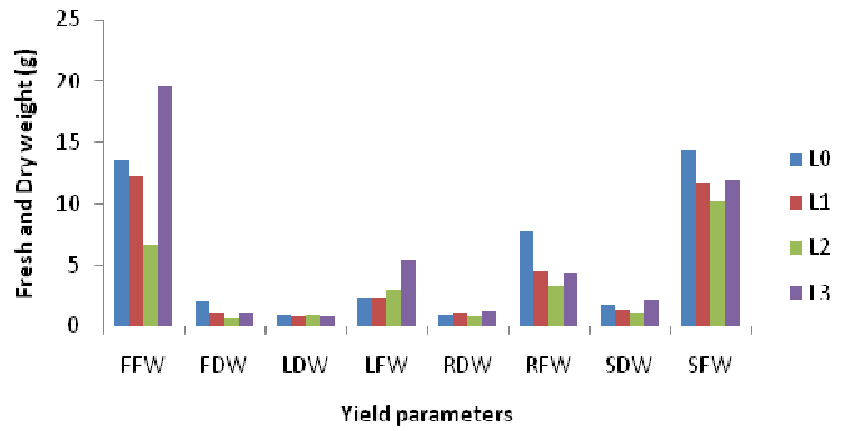

Fig. 3. Effect of light intensities on the yield parameters of two cultivars of okra in the pot experiment

The values are the mean of the two maize varieties under different light intensities; L0-Control/No reduction; L1- 33\% light reduction; L246\% light reduction; L3- 76\% light reduction; FFW = Fresh Fruit Weight; FDW = Fruit Dry Weight; LDW = Leaf Dry Weight; LFW $=$ Leaf Fresh weight; RDW = Root Dry Weight; RFW = Root Fresh Weight; SDW = Stem Dry Weight; SFW = Stem Fresh Weight

rates compared to control in V1. The trend was similar for V2 with C3 increasing the fruit and leaf fresh weights. L3 (76\% light reduction) in combination with $\mathrm{C} 2$ and $\mathrm{C} 1$ increased fruit and stem fresh weight of V1 compared to control, while the leaf fresh weight was increased with 
Table 6. Interactive effects of compost and light intensity on the dry matter accumulation of two cultivars of okra in the pot experiment

\begin{tabular}{|c|c|c|c|c|c|c|}
\hline $\begin{array}{c}\text { Light Intensity } \\
\text { (klux) }\end{array}$ & Cultivars & $\begin{array}{c}\text { Compost } \\
(\mathrm{t} / \mathrm{ha})\end{array}$ & $\begin{array}{c}\text { Dry leaves } \\
(\mathrm{g})\end{array}$ & $\begin{array}{c}\text { Dry root } \\
(\mathrm{g})\end{array}$ & $\begin{array}{l}\text { Dry fruit } \\
(\mathrm{g})\end{array}$ & $\begin{array}{c}\text { Dry Stem } \\
(\mathrm{g})\end{array}$ \\
\hline \multirow[t]{8}{*}{ L0 } & V1 & $\mathrm{C} 0$ & 0.39 & 1.51 & 2.45 & 1.78 \\
\hline & & $\mathrm{C} 1$ & 0.54 & 1.66 & 1.82 & 1.13 \\
\hline & & $\mathrm{C} 2$ & 0.96 & 1.53 & 3.12 & 1.42 \\
\hline & & C3 & 0.00 & 0.90 & 0.67 & 1.15 \\
\hline & V2 & $\mathrm{C} 0$ & 0.33 & 0.29 & 3.36 & 1.43 \\
\hline & & $\mathrm{C} 1$ & 0.61 & 0.78 & 2.14 & 5.27 \\
\hline & & $\mathrm{C} 2$ & 5.27 & 0.78 & 2.14 & 0.78 \\
\hline & & $\mathrm{C} 3$ & 0.35 & 0.70 & 0.67 & 1.15 \\
\hline \multirow[t]{8}{*}{ L1 } & V1 & $\mathrm{C} 0$ & 0.54 & 0.97 & 0.77 & 0.94 \\
\hline & & $\mathrm{C} 1$ & 1.91 & 0.97 & 1.34 & 1.18 \\
\hline & & $\mathrm{C} 2$ & 1.08 & 1.09 & 1.11 & 1.31 \\
\hline & & C3 & 0.80 & 0.68 & 0.74 & 1.62 \\
\hline & V2 & $\mathrm{C} 0$ & 0.75 & 1.76 & 1.97 & 2.17 \\
\hline & & $\mathrm{C} 1$ & 1.09 & 0.91 & 1.11 & 1.23 \\
\hline & & $\mathrm{C} 2$ & 0.43 & 1.54 & 1.00 & 1.75 \\
\hline & & C3 & 0.24 & 1.73 & 1.16 & 1.65 \\
\hline \multirow[t]{8}{*}{ L2 } & V1 & $\mathrm{C} 0$ & 1.81 & 1.81 & 0.37 & 0.55 \\
\hline & & $\mathrm{C} 1$ & 0.92 & 1.15 & 0.72 & 2.54 \\
\hline & & $\mathrm{C} 2$ & 0.64 & 0.78 & 0.84 & 1.05 \\
\hline & & C3 & 0.70 & 1.00 & 0.83 & 0.96 \\
\hline & V2 & $\mathrm{C} 0$ & 0.96 & 0.51 & 1.04 & 1.19 \\
\hline & & $\mathrm{C} 1$ & 0.96 & 0.60 & 0.67 & 0.90 \\
\hline & & $\mathrm{C} 2$ & 0.73 & 0.63 & 0.56 & 0.91 \\
\hline & & C3 & 0.62 & 0.30 & 0.51 & 1.31 \\
\hline \multirow[t]{8}{*}{ L3 } & V1 & $\mathrm{C} 0$ & 0.27 & 0.76 & 0.75 & 1.84 \\
\hline & & $\mathrm{C} 1$ & 0.67 & 0.97 & 1.51 & 2.63 \\
\hline & & $\mathrm{C} 2$ & 0.40 & 0.71 & 1.00 & 1.66 \\
\hline & & $\mathrm{C} 3$ & 0.77 & 1.15 & 0.78 & 2.84 \\
\hline & V2 & $\mathrm{C} 0$ & 0.67 & 1.46 & 1.50 & 2.42 \\
\hline & & $\mathrm{C} 1$ & 0.43 & 1.67 & 1.33 & 2.38 \\
\hline & & $\mathrm{C} 2$ & 1.76 & 2.80 & 1.50 & 2.09 \\
\hline & & C3 & 1.34 & 1.55 & 1.50 & 1.93 \\
\hline \multicolumn{3}{|l|}{$\begin{array}{l}\text { Prob. of ' } F \text { ' } \\
\text { LSD }\end{array}$} & NS & NS & NS & NS \\
\hline \multicolumn{3}{|l|}{ LSD } & 1.87 & 0.85 & 0.91 & 2.03 \\
\hline
\end{tabular}

application of C3. For variety 2, C2 was superior in combination with L3 in terms of leaf fresh weight (Table 5).

Statistically, the effect of light intensity on the dry matter accumulation was also not significant $(\mathrm{P}<0.05)$. However, in the two varieties, $\mathrm{C} 2$ increased the leaf dry matter production of okra under high light intensity (L0 = no reduction). The dry fruit weight was also increased with the application of $\mathrm{C} 2$ in V1. Root dry weight was also increased with the application of different rates of compost and they all performed better than control in V2. L1 enhanced leaf and stem dry matter production with the addition of compost to V1 compared to control. The fruit dry matter was also higher than control with $\mathrm{C} 1$ and C2. Dry matter production in V2 under L1 was not significant with compost addition compared to control. However, stem and fruit dry matter yield was better than control under L2 with the application of compost in V1, while the effect was also not significant in V2. With 76\% light intensity, leaf and root dry matter yield were enhanced with C2 and C3 (Table 6).

The effect of light intensity on the vegetative growth of an okra cultivar ('Clemson spine') on the field

The effect of light intensity on the vegetative growth of the okra cultivar ('Clemson spine') selected from the pot experiment on the field was similar to what was observed in the pot. The highest values for plant height, number of leaf, leaf area and number of fruits were recorded in plants grown under $76 \%$ light reduction (L3). This treatment was significantly $(\mathrm{P}<0.05)$ different from other treatments while control ( $0 \%$ reduction) had the least value. In respect to days to flower, okra plants under L0 commenced flowering earlier than those ones under light reductions (Table 7). Similarly, on the field, okra growth responded positively to compost application. The plant height was increased in soil amended with compost most especially at the rate of $15 \mathrm{t} / \mathrm{ha}$ followed by that of $5 \mathrm{t} / \mathrm{ha}$. The least mean was recorded in the control where there was no addition of compost. Also, number of leaf was more in okra plants treated with $15 \mathrm{t} / \mathrm{ha}$ (C3) which also had the highest value followed by those treated with 5 $\mathrm{t} / \mathrm{ha}$ and the least mean was recorded in the control (no compost). However, in respect of day to flower, there was a delay in those grown in compost amended soil compared to control. The effect of compost application on the leaf area and number of fruit was also remarkable though not statistically significant, and plant treated with $15 \mathrm{t} / \mathrm{ha}$ had the highest leaf area and number of fruit followed by $\mathrm{C} 1$ treatment, while the least value was recorded in the control (Table 8). 
Table 7. Effect of light intensity on the vegetative growth of okra on the field

\begin{tabular}{lccccc}
\hline $\begin{array}{c}\text { Light } \\
\text { intensity } \\
(\mathrm{klux})\end{array}$ & $\begin{array}{c}\text { Plant } \\
\text { height } \\
(\mathrm{cm})\end{array}$ & $\begin{array}{c}\text { Number } \\
\text { of leaves } \\
(\mathrm{no})\end{array}$ & $\begin{array}{c}\text { Days to } \\
\text { flower } \\
(\mathrm{no})\end{array}$ & $\begin{array}{c}\text { Leaf } \\
\text { area } \\
\left(\mathrm{cm}^{2}\right)\end{array}$ & $\begin{array}{c}\text { Numbers } \\
\text { of fruit } \\
(\mathrm{no})\end{array}$ \\
\hline L0 & 30.21 & 5.38 & 28.81 & 36.70 & 3.61 \\
L1 & 32.42 & 5.70 & 30.00 & 44.30 & 1.79 \\
L3 & 36.85 & 6.33 & 34.00 & 54.00 & 5.42 \\
Prob. of 'F' & $\mathrm{X}$ & $\mathrm{X}$ & $\mathrm{X}$ & $\mathrm{X}$ & $\mathrm{X}$ \\
\hline LSD & 2.05 & 0.88 & 1.23 & 5.31 & 1.28 \\
\hline
\end{tabular}

Mean along the same column with the same alphabet are not significantly different at $\mathrm{P}<0.05$; Ns: Not Significant at $\mathrm{P}<0.05$; $\mathrm{X}=$ Significant difference at $\mathrm{P}<0.05$; L0- Control; $\mathrm{L} 1=33 \%$ light reduction; $\mathrm{L} 3=76 \%$ light reduction; LSD $=$ Least Significant Difference

Table 8. Effect of compost application on the vegetative growth of okra on the field

\begin{tabular}{lccccc}
\hline $\begin{array}{c}\text { Compost } \\
\text { level }(\mathrm{t} / \mathrm{ha})\end{array}$ & $\begin{array}{c}\text { Plant } \\
\text { height } \\
(\mathrm{cm})\end{array}$ & $\begin{array}{c}\text { Number } \\
\text { of leaves }\end{array}$ & $\begin{array}{c}\text { Days to } \\
\text { flower }\end{array}$ & $\begin{array}{c}\text { Leaf } \\
\text { area } \\
\left(\mathrm{cm}^{2}\right)\end{array}$ & $\begin{array}{c}\text { Numbers } \\
\text { of fruit } \\
(\mathrm{no})\end{array}$ \\
\hline C0 & 30.18 & 5.41 & 30.58 & 43.10 & 1.72 \\
C1 & 34.32 & 6.10 & 30.70 & 43.60 & 2.32 \\
C3 & 35.98 & 6.80 & 33.38 & 48.20 & 2.87 \\
Prob. of 'F' & $\mathrm{X}$ & $\mathrm{NS}$ & $\mathrm{X}$ & $\mathrm{X}$ & $\mathrm{NS}$ \\
LSD & 2.05 & 0.88 & 1.23 & 5.31 & 1.48 \\
\hline
\end{tabular}

Mean along the same column with the same alphabet are not significantly different at $\mathrm{P}<0.05$; Ns: Not Significant at $\mathrm{P}<0.05$; X: Significant difference at $\mathrm{P}$ $<0.05$; C0-Control; $\mathrm{C} 1=5 \mathrm{t} / \mathrm{ha} ; \mathrm{C} 2=10 \mathrm{t} / \mathrm{ha}$; $\mathrm{C} 3=15 \mathrm{t} / \mathrm{ha}$; $\mathrm{LSD}=$ Least Significant Difference
Table 9. Interactive effects of compost application and light intensity on the vegetative growth of okra on the field

\begin{tabular}{lcccccc}
\hline $\begin{array}{c}\text { Light } \\
\text { intensity } \\
\text { (Klux) }\end{array}$ & $\begin{array}{c}\text { Compost } \\
\text { t/ha }\end{array}$ & $\begin{array}{c}\text { Plants } \\
\text { height } \\
(\mathrm{cm})\end{array}$ & $\begin{array}{c}\text { Noof } \\
\text { leaves } \\
(\mathrm{no})\end{array}$ & $\begin{array}{c}\text { Days to } \\
\text { flower } \\
(\mathrm{no})\end{array}$ & $\begin{array}{c}\text { Leaf } \\
\text { area } \\
\left(\mathrm{cm}^{2}\right)\end{array}$ & $\begin{array}{c}\text { Number } \\
\text { offruit } \\
(\mathrm{no})\end{array}$ \\
\hline L0 & C0 & 28.19 & 5.19 & 27.84 & 37.11 & 1.56 \\
& $\mathrm{C} 1$ & 31.74 & 6.64 & 28.54 & 35.22 & 4.25 \\
& $\mathrm{C} 3$ & 30.71 & 5.53 & 30.06 & 37.83 & 2.02 \\
L1 & C0 & 28.69 & 5.26 & 29.69 & 42.06 & 1.36 \\
& $\mathrm{C} 1$ & 34.15 & 5.15 & 29.93 & 41.64 & 1.87 \\
& $\mathrm{C} 3$ & 34.42 & 5.37 & 30.03 & 49.25 & 2.13 \\
L3 & $\mathrm{C} 0$ & 33.65 & 5.80 & 34.20 & 51.19 & 2.24 \\
& $\mathrm{C} 1$ & 37.07 & 6.52 & 33.62 & 52.98 & 2.07 \\
& $\mathrm{C} 3$ & 39.87 & 7.30 & 37.76 & 57.50 & 2.96 \\
Prob. of 'F' & & $\mathrm{NS}$ & $\mathrm{NS}$ & $\mathrm{NS}$ & $\mathrm{NS}$ & $\mathrm{NS}$ \\
LSD & & 3.55 & 1.53 & 2.13 & 9.21 & 2.56 \\
\hline
\end{tabular}

Ns: Not Significant at P < 0.05; L0-Control; L1- 46\% light reduction; L3- 76\% light reduction; C0- Control; C1 $=5 \mathrm{t} / \mathrm{ha}$; $3=15 \mathrm{t} / \mathrm{ha}$; $\mathrm{LDD}=$ Least Significant Difference

t/ha compost. The interactive effect of compost application and light intensity was more significant under $76 \%$ light reduction and highest compost application (L3 x C3). There were increases in plant height, leaf area, number of leaf and fruit compared to control and other treatments. There were

Table 10.Effect of compost application and light intensity on the yield parameter of okra on the field

\begin{tabular}{|c|c|c|c|c|c|c|c|c|}
\hline \multirow{2}{*}{ Yield parameters (g) } & \multicolumn{3}{|c|}{ Compost rates } & \multicolumn{5}{|c|}{ Light intensities } \\
\hline & $\mathrm{CO}$ & $\mathrm{C} 1$ & C3 & LSD & L0 & L1 & L3 & LSD \\
\hline FFW & $28.95 b$ & $48.54 a$ & $51.99 \mathrm{a}$ & 9.08 & $41.70 \mathrm{a}$ & $41.40 \mathrm{a}$ & $46.40 \mathrm{a}$ & 9.08 \\
\hline FDW & $5.64 b$ & $8.15 a$ & $8.07 \mathrm{a}$ & 2.09 & $7.52 \mathrm{a}$ & $6.73 a$ & $7.61 \mathrm{a}$ & 1.27 \\
\hline LFW & $5.42 b$ & $6.67 \mathrm{~b}$ & $9.15 \mathrm{a}$ & 3.18 & $6.02 \mathrm{a}$ & $7.22 \mathrm{a}$ & $7.98 \mathrm{a}$ & 1.84 \\
\hline LDW & $0.78 b$ & $0.98 \mathrm{~b}$ & $1.36 \mathrm{a}$ & 0.46 & $0.94 \mathrm{a}$ & $1.81 \mathrm{a}$ & $1.96 \mathrm{a}$ & 0.26 \\
\hline SFW & $14.71 \mathrm{~b}$ & $27.51 \mathrm{a}$ & $30.12 \mathrm{a}$ & 4.97 & $22.21 \mathrm{a}$ & $25.33 a$ & $24.80 \mathrm{a}$ & 4.97 \\
\hline SDW & $1.59 \mathrm{~b}$ & $2.24 \mathrm{a}$ & $2.44 \mathrm{a}$ & 0.56 & $2.06 \mathrm{a}$ & $2.13 a$ & $2.07 \mathrm{a}$ & 0.33 \\
\hline RFW & $8.33 c$ & $11.35 \mathrm{~b}$ & $15.95 a$ & 1.90 & $9.54 \mathrm{~b}$ & $9.35 \mathrm{~b}$ & $16.75 \mathrm{a}$ & 1.90 \\
\hline RDW & $1.24 \mathrm{a}$ & $2.79 \mathrm{a}$ & $3.46 \mathrm{a}$ & 2.71 & $1.53 \mathrm{ab}$ & $1.28 \mathrm{~b}$ & $3.08 \mathrm{a}$ & 1.56 \\
\hline
\end{tabular}

Mean along the same row with the same alphabet for compost rate or light intensity are not significantly different at $\mathrm{P}<0.05$; C0- Control; $\mathrm{C} 1=5 \mathrm{t} / \mathrm{ha}$; $\mathrm{C} 3=15 \mathrm{t} / \mathrm{ha}$; L0- Control/No reduction; L1- 33\% light reduction; L3- 76\% light reduction; FFW = Fresh Fruit Weight; FDW = Fruit Dry Weight; LDW = Leaf Dry Weight; LFW $=$ Leaf Fresh Weight; RDW = Root Dry Weight; RFW = Root Fresh Weight; SDW = Stem Dry Weight; SFW = Stem Fresh Weight; LSD = Least Significant Difference

Table 11. Interactive effect of compost application on theyield parameters of okra on the field

\begin{tabular}{|c|c|c|c|c|c|c|c|c|c|}
\hline Intensity & Compost & $\begin{array}{c}\text { Fresh leaves } \\
(\mathrm{g})\end{array}$ & $\begin{array}{l}\text { Dry leaves } \\
\text { (g) }\end{array}$ & $\begin{array}{c}\text { Fresh } \\
\text { root } \\
(\mathrm{g})\end{array}$ & $\begin{array}{c}\text { Dry } \\
\text { root } \\
(\mathrm{g})\end{array}$ & $\begin{array}{c}\text { Fresh fruit } \\
\text { (g) }\end{array}$ & $\begin{array}{l}\text { Dry fruit } \\
\text { (g) }\end{array}$ & $\begin{array}{c}\text { Fresh stem } \\
\text { (g) }\end{array}$ & $\begin{array}{c}\text { Dry stem } \\
\text { (g) }\end{array}$ \\
\hline \multirow[t]{3}{*}{ L0 } & $\mathrm{C} 0$ & 4.20 & 0.55 & 6.07 & 0.96 & 28.42 & 4.86 & 13.89 & 1.36 \\
\hline & $\mathrm{C} 1$ & 7.27 & 1.00 & 9.15 & 1.66 & 54.27 & 10.64 & 22.08 & 2.12 \\
\hline & $\mathrm{C} 3$ & 9.61 & 1.29 & 13.44 & 1.96 & 42.27 & 7.08 & 30.65 & 2.14 \\
\hline \multirow[t]{3}{*}{ L1 } & $\mathrm{C} 0$ & 4.81 & 0.77 & 5.33 & 0.82 & 22.95 & 5.77 & 14.70 & 1.68 \\
\hline & $\mathrm{C} 1$ & 4.87 & 1.49 & 9.81 & 1.44 & 45.56 & 5.66 & 30.53 & 2.25 \\
\hline & $\mathrm{C} 3$ & 9.02 & 1.64 & 12.71 & 1.58 & 55.83 & 8.76 & 30.75 & 2.48 \\
\hline \multirow[t]{3}{*}{ L3 } & $\mathrm{C} 0$ & 7.26 & 1.04 & 13.48 & 1.94 & 35.47 & 6.29 & 15.53 & 1.73 \\
\hline & $\mathrm{C} 1$ & 7.86 & 0.81 & 15.09 & 5.30 & 45.80 & 8.16 & 29.93 & 2.34 \\
\hline & $\mathrm{C} 3$ & 8.81 & 1.61 & 21.68 & 2.00 & 57.80 & 8.38 & 28.96 & 2.74 \\
\hline Prob of $F$ & & NS & NS & NS & NS & NS & $\mathrm{X}$ & NS & NS \\
\hline LSD & & 3.18 & 0.46 & 3.29 & 2.71 & 15.73 & 2.09 & 8,61 & 0.57 \\
\hline
\end{tabular}

Ns: Not Significant at P < 0.05; X: Significant difference at P < 0.05; C0- Control; C1 = 5 t/ha; C3 = 15 t/ha; L0- Control/No reduction; L1- 33\% light reduction; L3$76 \%$ light reduction; LSD = Least Significant Difference

Interactive effect of compost application and light intensity on the vegetative growth of okra on the field

Generally, across the treatments for light intensity interacting with compost application, the highest mean values were recorded in the plants treated with $37.5 \mathrm{~g}$ or 15 no significant $(\mathrm{P}<0.05)$ differences in the interaction between compost application and high light intensity, though the interaction reveals that mean height and number of fruit increased in plants treated with $12.5 \mathrm{~g}$ or $5 \mathrm{t} / \mathrm{ha}$ of compost compared to $\mathrm{L} 0 \times \mathrm{C} 0$ and $\mathrm{L} 0 \times \mathrm{C} 3$, which had smaller values. 
224

Normal light (L0) interacting with compost at all levels showed that plants treated with $12.5 \mathrm{~g}$ or $5 \mathrm{t} / \mathrm{ha}$ had the highest mean values for plant height and number of leaf and fruit, while the least were recorded in the control (no compost). 33\% light intensity (L1) interacting with $15 \mathrm{t} / \mathrm{ha}$ compost also had the highest mean for plant height, number of leaf, leaf area and number of fruit. The interactive effect of compost and light intensity on days to flower showed that the plants under normal light (no light reduction) and no compost $(\mathrm{C} 0)$ had the least mean across the treatments, which means that flowering was hastened under this light intensity, while the plants grown under low light intensity $(\mathrm{L} 3=76 \%)$ and $15 \mathrm{t} / \mathrm{ha}$ compost had the highest mean across the treatments though there were no significant differences among the means. Moreover, the interactive effect of compost application and light intensity on leaf area showed that okra plants grown under high light intensity or no light reduction (LO) had the least mean values compared to the other light treatments. Whereas, plant with low light intensity (33 and $76 \%$ light reduction) and $15 \mathrm{t} / \mathrm{ha}$ of compost had the highest mean (Table 9).

\section{The effect of compost application and light intensity on the yield parameters of okra on the field}

Though, under low light intensity (76\% light reduction L3) there was an increase in the fruit fresh and dry weight compared to other means recorded, but the effect of light intensity on the yield parameters of okra in the field generally showed that there was no significant $(P<0.05)$ difference among all the parameters measured, except for root fresh and dry weight. Compost application however had significant effect on all yield parameters compared to the control, with higher compost rate performing better than lower rate. The fresh weight was significantly $(\mathrm{P}<0.05)$ higher in plant treated with $15 \mathrm{t} / \mathrm{ha}$ compost (Table 10). The interactive effect of light intensity and various levels of compost application on the yield parameters showed that plants treated with compost at $15 \mathrm{t} / \mathrm{h}$ h had the highest value under various light intensity. Application of $15 \mathrm{t} / \mathrm{ha}$ of compost increased the fresh and dry weight of okra and the lowest was recorded in the control. Furthermore, across the treatment the interaction between varying level of light intensity (L0, $\mathrm{L} 1, \mathrm{~L} 3)$ and compost $(\mathrm{C} 0, \mathrm{C} 1, \mathrm{C} 2)$ on the fresh fruit weight showed that the highest fresh fruit weight was recorded under low light intensity (L3 $=76 \%$ light reduction) with $15 \mathrm{t} / \mathrm{ha}$ of compost, while the lowest mean was recorded under the normal light intensity (L0, control) without compost (C0, control) (Table 11).

\section{Discussions}

The effect of compost and light intensity in both trials showed that the performance of okra was generally improved with the application of compost and reduction in the light intensity. This was reflected in the interactive effect of compost application and light intensity on the growth and yield parameters of okra. At high light intensity where the plants were exposed to intense rays of light, which probably might have also increased the rate of transpiration in plants, but with the application of compost, the stress effect of excessive heat was minimized. Rather, there was an increase in growth and yield parameters compared to control. The ability of compost to enrich the soil with required nutrients definitely contributed significantly to the yield of okra under varying light intensities (Akande et al., 2004; Ojeniyi and Olamilua, 2005; Premsekhar and Rajashree, 2009). Compost also has the ability to increase the soil water holding capacity which in-turn could have enhanced the water balance in the soil (Adediran et al., 2004; Sanwal et al., 2007).

Differences were however observed in the response of okra in the pot and field experiments. The observation on the field showed that the effect of light on okra growth was more pronounced than what was recorded in the pot experiment. In the pot, $33 \%$ reduction in light intensity, produced more fruits, $76 \%$ light reduction also reduced the number of days to flower whereas leaf area and number of leaf were not affected. On the field, leaf area, plant height, number of leaf and number of fruits were enhanced under reduced light intensity $(76 \%$ reduction) contrary to what was found in the pot experiment. This was not surprising, as plants generally perform and respond to treatments under field (natural) conditions better than when cultivated in pots where their growth and potentials are restricted. The positive effect of shade (reduction in light intensity) on leaf area and number of leaf on the field however contradicted other reports where shade reduced leaf area formation as well as number of leaf(Wilson and Coope, 1969). Reduction in light intensity prolonged the number of days to flower and this agreed with the previous report that light reduction reduces the rate of photosynthesis, which in turn would have affected the growth and developmental processes (Grabau et al., 1990). Growth of pollen tube was reportedly impaired with reduction in light intensity, thereby delaying fertilization and fruiting (Campbell et al., 2001) as observed in this study. The okra plants grown under reduced light intensities were still fruiting later than those ones under high light intensity have started shedding their leaves. This accounted for the increase in number of fruits recorded in reduced light intensities despite the fact that those under 100\% light intensity started fruiting earlier. Excessive light intensity has been reported to scorch/burn the leaves and reduce crop yields (Edmond et al., 1978). It also reduces the chlorophyll content, which in turn reduces the rate of light absorption and the rate of photosynthesis. This is because excess light intensity is associated with increase in the temperature of leaves and this will lead to rapid transpiration and water loss. The guard cells are said to lose turgor. The stomata are also partially or completely closed and the rate of diffusion of carbon dioxide into the leaves slows down (Wilson and Coope, 1969). The rate of photosynthesis decreases while respiration continues, resulting in low availability of carbohydrates for growth and development. The high leaf temperature also inactivates all the enzymatic system, especially those that changes sugars to starch. Physiologically, an increase in the accumulation of sugar in the stroma of chloroplast prevents or slows down photosynthesis.

Similarly, compost effect was not significant on the growth parameters in the pot whereas, on the field, plant height, number of leaf, number of flower and leaf area increased significantly with increase in compost rates irrespective of light intensity and crop variety. Under high light intensity however, compost application was a relieve, probably due to the scorching effect of high light intensity as revealed by the performance of treated okra in terms of all the vegetative parameters compared to control (LOCO). The variation in the response of okra varieties to the light intensity and compost 
amendments could be due to their genetic make- up because crop response to different growth managements is a factor of its genetic compositions (Aladele et al., 2008; Manjanbu et al., 1986; Odeleye et al., 2005). 'Clemson' in particular has been reported to respond positively both to fertilizer amendments and different light intensities (Kansal et al., 1981; Knorr and Vogtmann, 1983; Odeleye et al., 2005). Therefore, the major factors affecting the behavior of field crops, fruits and vegetables are their variety and management practices.

Reduction in light intensity as well as compost application also had positive effect on fresh and dry matter yield compared to control. When considered singly, the effect of both compost and light intensity was significant. Similarly, their interaction was also remarkable both in the pot and on the field. This kind of positive influence of compost on okra dry matter production and partitioning was in accordance with what has been reported previously on the ability of compost in enhancing proper physiological processes in crop plants (Adediran et al., 2001; Adejumo et al., 2010; Katung et al., 1996; NIHORT, 1986). The higher dry matter production by the okra plants treated with higher compost rates could have resulted from availability of enough nutrients, which consequently enhanced plant metabolic processes. When nutrient is in the right proportion, the photosynthetic activity of the plants will also be considerably favored, as a result of improved light interception (Subbarao and Ravi, 2001). This was linked to the availability of adequate amount of nutrients for plant use that improves their vegetative growth and efficient translocation of photosynthates from source to sink. In addition, it has also been observed that organic manures increases soil water holding capacity and this means that those nutrients would be more readily available to crops where manures have been added to the soil (Dada and Fayinminnu, 2010).

\section{Conclusions}

It is however concluded that optimal performance of okra all the year round could be enhanced with compost application at $15 \mathrm{t} / \mathrm{ha}$ (C3) coupled with low light intensity (L3). Low light intensity ( $76 \%$ light reduction) increased the growth parameters, but delayed flowering. In combination with higher compost rates, it enhanced prolonged fruiting and leaf formation in the two okra varieties. High light intensity (L1) though enhanced leaf area formation and early flowering, it hastened leaf senescence and abscission. Compost generally increased leaf area and dry matter accumulation of the two okra cultivars compared with control under varying light intensities, with the higher rate $(15 \mathrm{t} / \mathrm{ha})$ being superior. Between the two cultivars, 'Clemson spine' performed better than 'NH47-4' in terms of yield. It grows faster and produces more fruits especially at high compost application.

\section{References}

Adediran JA, Taiwo LB, Sobulo RA (2001). Effect of organic wastes and method of composting on compost maturity, nutrient composition of compost and yields of two vegetable crops. Journal of Sustainable Agriculture 22(4):95-109.

Adediran JA, Taiwo LB, Akande MO, Sobulo RA, Idowu OJ
(2004). Application of organic and inorganic fertilizer for sustainable maize and cowpea yields in Nigeria. Journal of Plant Nutrition 27(7):1163-1181.

Adejumo SA, Togun AO, Adediran JA, Ogundiran MB (2010). Effects of compost application on remediation and the growth of maize planted on lead contaminated soil. Conference proceedings of 19th World Congress of Soil Science, Soil Solutions for a Changing World pp 99-102.

Adeniyan ON, Ojeniyi SO (2003). Comparative effectiveness of different levels of poultry manure with NPK fertilizer on residual soil fertility, nutrient uptake and yield of maize. Moor Journal of Agricultural Research 4(2):191-197.

Agbogidi OM, Nweke FU (2005). Effects of crude oil polluted soil on the performance of okra (Abelmoschus esculentus) Moench in Delta State. African Journal of Natural Sciences 8: 31-35.

Akanbi WB (2002). Growth, nutrient uptake and yield of maize and okra as influenced by compost and nitrogen fertilizer under different cropping systems. PhD Thesis, University of Ibadan, Nigeria, 228 pp.

Akanbi WB, Adediran JA, Togun AO, Sobulo RA (2000). Effect of organic-base fertilizer on the growth, yield and storage life of tomato (Lycopersicon eculentum Mill). Bioscience Research Communication 12(4):439-444.

Akande MO, Oluwatoyinbo FI, Adediran JA, Buari KW, Yusuf IO (2004). Soil amendments affect the release of $P$ from rock phosphate and the development and yield of okra. Journal of Vegetable Crop Production 9(2):3-9.

Akintoye HA, Adebayo AG, Aina OO (2011). Growth and yield response of okra intercropped with live mulches. Asian Journal of Agricultural Research 5(2):146-153.

Akinyele BO, Temikotan T (2007). Effect of variation in soil texture on the vegetative and pod characteristics of okra (Abelmoschus esculentus (L.) Moench). International Journal of Agricultural Research 2(2):165-169.

Aladele SE, Ariyo OJ, de Lapena R (2008). Genetic relationship among West African okra (Abelmoschus caillei) and Asian genotypes (Abelmoschus esculentus) using RAPD. African Journal of Biotechnology 7(10):1426-1431.

Campbell AW, Griffin WB, Burrit DJ, Conner AJ (2001). The importance of light intensity for pollen tube growth and embryo survival in wheat and maize crosses. Annals of Botany 87(4):517-522.

Dada OA, Fayinminnu OO (2010). Period of weed control in okra [Abelmoschus esculentus (L.) Moench] as influenced by varying rates of cattle dung and weeding regimes. Notulae Botanicae Horti Agrobotanici Cluj-Napoca 38(1):149-154.

Edmond JB, Senn TL, Andrews FS, Halfacre RG (1978). Fundamentals of Horticulture. 4th Edition. McGraw-Hill Inc pp 109-130.

El-Magd A, El-Bassiony M, Fawzy ZF (2006). Effect of organic manure with or without chemical fertilizers on growth, yield and quality of some varieties of Broccoli plants. Journal of Applied Sciences Research 2(10):791-798.

Garg S, Bahla GS (2008). Phosphorus availability to maize as influenced by organic manures and fertilizer $\mathrm{P}$ associated phosphatase activity in soils. Bioresource Technology 99(13):5773-5777.

Grabau LJ, Van Sanford DA, Meng QW (1990). Reproductive 
226

characteristics of winter wheat cultivars subjected to postanthesis shading. CropScience 30(4):771-774.

Haynes RJ, Naidu R (1998). Influence of lime, fertilizer and manure applications on soil organic matter content and soil physical conditionsa review. Nutrient Cycling in Agroecosystems 51(2):123-137.

ITA (International Institute of Tropical Agriculture) (1979). Selected methods for soil and plant analysis. Manual Series-International Institute of Tropical Agriculture (Nigeria) (1).

Kansal BD, Singh B, Balaj KL, Kaur G (1981). Effects of different levels of nitrogen and farmyard manure on yield and quantity of spinach (Spinacea oleracea L.). Plant Foods for Human Nutrition 31(2):163170.

Katung MD, Olanrewaju JD, Gupta US, Kureh I (1996). Fruit and seed yields of okra as influenced by farm yard manure and Nitrogen fertilizer. In Proc. $14^{\text {th }}$ HORTSON Conference Ago-Iwoye, 14 April, 1996.

Knorr D, Vogtmann H (1983). Quality and quantity determination of ecologically grown foods. In: Sustainable Food Systems. Knorr D (Ed). AVI Publishing Co, Westport, Connecticut pp 352-381.

Majanbu IS, Ogunlela VB, Ahmed MK (1986). Response of two okra (Abelmoschus esculentus L. Moench) varieties to fertilizers: Growth and nutrient concentration as influenced by nitrogen and phosphorus application. Fertilizer Research 8(3):297-306.

Moekchantuk T, Kumar P (2004). Export okra production in Thailand. Inter-country programme for vegetable IPM in South \& SE Asia phase II. Food \& Agriculture Organization of the United Nations, Bangkok, Thailand.

NIHORT - National Horticultural Research Institute (1986). Advances in fruit and vegetable research at NIHORT (1978-1986), pp 62.

Odeleye FO, Odeleye OM, Dada OA, Olaleye AO (2005). The response of okra to varying levels of poultry manure and plant population density under sole cropping. Journal of Food Agriculture and Environment 3(3/4):68.
Ojeniyi SO, Olamilua AI (2006). Effect of poultry manure on nutrient composition, growth and yield of Okra. Proceeding of the 23rd annual conference of the horticulture society of Nigeria pp 136-139.

Olasantan FO (1991). Response of tomato and okra to nitrogen fertilizer in sole cropping and intercropping with cowpea. Journal of Horticultural Science 66:191-199.

Premsekhar M, Rajashree V (2009). Influence of organic manures on growth, yield and quality of okra. American Eurasian Journal of Sustainable Agriculture 3(1):6-8.

Sanwal SK, Laxminarayana K, Yadav RK, Rai N, Yadav DS, Bhuyan M (2007). Effect of organic manures on soil fertility, growth, physiology, yield and quality of turmeric. Indian Journal of Horticulture 64(4):444-449.

Schippers RR (2000). African indigenous vegetables: An overview of the cultivated species. Natural Resource Institute/ACP-EU Technical Centre for Agricultural and Rural Cooperation, Chatham. UK Sci and Biotech 74(2):206-212.

Subbarao TSS, Ravi Shankar C (2001). Effect of organic manures on growth and yield of brinjal. South Ind Hort 49(Special):288-291.

Vergara BS (1978). Crop response to light variations. In: Gupta US, Ed Crop Physiology. New Delhi, Oxford \& IB Publishing Co pp 137156.

Wilson D, Coope JP (1969). Effects of light intensity during growth on leafanatomy and subsequent light saturated photosynthesis among contrasting Lolium genotypes. New Phytologist 68(4):1225-1135. 